\title{
NEED OF THE TIME: UNDERSTANDING CHILD'S PHYSICAL AND PSYCHOLOGICAL GROWTH AND DEVELOPMENT AND FACTORS AFFECTING THEM
}

\author{
Shivani Sharma
}

\begin{abstract}
We are living in $21^{\text {st }}$ century: a world dominated by best digital technologies, an era of absolute wonders. Today we are globalized and about next to everything is accessible for us. Today, it is possible for us to collect knowledge about anything and stay connected to anybody in any part of this world but what about the people living with us specially the young and innocent souls, our kids? Are we closer enough to them to understand them, to feel connected to them? In this fast pacing era people blame technologies and gadgets for the present condition of our children. But is it the truth?
\end{abstract}

\section{INTRODUCTION}

Society evolved as the time changed which was much needed, but this evolution bought many problems with it among them disconnection is a big issue faced by many individuals. Today people are so engrossed in their lives that barely time is left to connect with anybody including their families. Elders understand the needs of today's lifestyles, but problems start when we stop connecting to our kids. As the proverb goes "All fingers are not the same" similarly all children are not same. Every child has a completely different psychology. Each child grows with its own pace and understands a condition completely differently. Growth and Development of a child go hand in hand it takes place in 3 different levels physical level, mental level and emotional level and if one of them is hindered due to unknown reasons then the child falls in special category.

Growth - It is the change of physical aspects of a child it is defined as an increase in the size of an individual due to increase in all number $\&$ size of the cells, resulting in an overall increase. This increase can be seen, appreciated \& measured accurately.

Stages of growth of a child includes

1.Infancy

2.Early childhood

3.Childhood

\section{Adolescents}

5.Adulthood

Human stages of growth are differentiated by age height and weight of an individual. Psychomotor development is progress in mental and motor skill activity. The process of growing and developing begins on the cellular level even before conception in the womb and continues throughout life until death. The period between birth and adulthood is commonly divided into five growth stages: infancy, early childhood, childhood, adolescence and adulthood. Although every child does not stay within the same time frame in growth.

In the period of Infancy, a baby is considered an infant from birth through the first year of life. During this first year, babies develop gross motor skills, fine motor skills Sensory skills, Language skills and social skills. In the early childhood a child is mobile and exploratory and develops a sense of right and wrong. In the childhood a child start noticing the physical changes of puberty, he starts focusing on goal setting. It is a time of stress for children as peer pressure takes its toll. The age of Adolescence enters from ages 12 to 18 years where children experience distinct mental and physical changes. Adolescent behavior often includes the teenagers recede from parents and authority figures to come more self-centered. In middle to late adolescence, teenagers are often characterized as becoming more comfortable with their body sexually. The final stage is Adulthood, it is often noted when a person is considered chronologically, legally and behaviorally ready to hold responsibilities such as: operating a motor vehicle, voting, taking the vows of marriage etc. The process of becoming mature does not end with adolescence but continues throughout adulthood as psychological, safety and selfactualization needs are met.

Factors influencing growth in children

1.Genetic

2. Environmental

3. Exercise and Health

4. Nutrition

5. Socio-Economic Status 


\section{International Journal of Engineering Applied Sciences and Technology, 2020 \\ Vol. 5, Issue 5, ISSN No. 2455-2143, Pages 308-311 \\ Published Online September 2020 in IJEAST (http://www.ijeast.com)}

1. Genetic - The most important factor that influences the growth of a child is the genetic material. This genetic material is responsible of transmission of physical characters from parents to a child.it influences the hair, eye

color, height of a child, weight of a child, skin color. Through genetic material diseases like diabetes, obesity, heart disease etc. are also passed to kids. however, nurturing a child in a best possible way can overcome some of these complications.

2. Environmental - An environment plays a vital role in the growth of a child as it is responsible for both the physical and psychological stimulation a child receives. As we know environment influences the learning, understanding and thinking process of an individual. A good school, an understanding and loving family, a peaceful environment with all the basic facilities provided to a child; these assist a child in its overall wellbeing and a child excels in almost all the fields of life. This will be completely vice versa case in completely opposite environment.

3. Exercise and Health - Balanced intake of food and proper exercise keeps a child healthy. Good health constitutes to a good immune system which helps a child to fight off disease easily. As the proverb says, "A healthy mind lives in a healthy body", so a healthy mind prepares a child to take challenges of life in a better way with positive attitude.

4. Nutrition - Nutrition is the study of nutrients in food. It gives us a detail study of how the body uses nutrients from food and the relationship between diet, health and disease. Nutrients helps a body to function properly and stay healthy. A balanced diet that is rich in vitamins, minerals, proteins, carbohydrates and fats is essential for the development of the brain and body. So proper nutrition is very important for proper growth of a child.

5. Socio-Economic Status - The socio-economic status of a family defines the position of a family in society based on factors like education, income, type of occupation, place of residence etc. A socially and economically sound family provides a child better opportunity in every aspect of life whether it is education, educational resources, clothing,

Development - It is the overall and progressive change of a child it involves the biological, psychological and emotional changes that occurs in a child; therefore, development is a multidimensional process.

Stages of development

1.Physical development

2.Cognitive development

3.Language development

4.Social development

5.Emotional development

Wholistic development sees the child as a whole person physically, emotionally, intellectually, socially, morally, culturally and spiritually. Learning about child development involves studying the patterns of growth and development.
Developmental norms are recognized pattern of development that children are expected to follow. Each child develops in a unique way; however, using norms helps in understanding these general patterns of development.

The development of your child's communication, behavior, social and other skills develop at different rates. Most skills develop in the same order, but the age they happen might vary even for children in the same family, development is different for every child.

Factors influencing development in children

1.Environmental

2.Social

3.Economical

4.Health

5.Living space

1.Environmental - Parents behavior towards their children shows in the personality of a child. More a child is loved, cared and is connected and bonded with his family more he feels accepted, confident, contented and attached with family. In contrast to the children who lives in abusive and neglected families. Family is the first school in a child life and so is a vital aspect of his development. A healthy environment is very important for a healthy mental development in a child it helps to protect and nurture a child emotionally and physically.

2.Social - The geographical topography is important in a child's education as the school where he studies is easily accessible, then the school they attend is whether public or private also matters as the opportunities given by schools are poles apart, then the neighborhood where he lives his peers, the religion a child is born into are some of the social causes in a child's life which becomes the base of a child development.

3.Economical- It is not a surprise that money is a deciding factor when it comes to living comfortably. It has been well established that the privilege of wealth is real and that it has a greater impact on childhood development than education. For instance, rich parents can afford to spend more time with their children and poorer parents are too caught up in making ends meet to have the privilege of quality time. Wealth also helps secure better academic training, opportunities for travel, extra classes, and so on.

4.Health - June 22, 2000 (Atlanta) -- Chronically ill children tend to be more submissive and less socially outgoing than healthy children. Further, kids who live with pain and physical restrictions may be more likely to have problems relating their peers. Now chronically ill children have many problems to deal with whatever they do they are unable to live a normal life. They are unable to participate in group activities. So health is also a break-in the development of a child.

5.Living space - The effect of living spaces on child development cannot be understated, and this includes the physical surroundings they are raised in. If your living 


\section{International Journal of Engineering Applied Sciences and Technology, 2020 \\ Vol. 5, Issue 5, ISSN No. 2455-2143, Pages 308-311 \\ Published Online September 2020 in IJEAST (http://www.ijeast.com)}

environment is cramped, noisy and filled with aggression, your child's personality can be affected. If you have too many people living at home and if the attention towards him is divided, he may seek out alternative forms of attention

which can lead to an emotional distance between him/her and you. Similarly, unpleasant surroundings often cause children to block out or bury negativity, making them more introverted.

\section{What children need}

\section{Children need meaningful connections}

Family is the most important part in children's life. Children need meaningful connections specially with their family members they love bonding with them. Going for picnics, going for walks, cuddling, playing indoor and outdoor games makes them feel loved and cared.

\section{Children need time to play}

It is very important for children to play. Indulging in outdoor activities makes children physically and mentally fit. It develops social skills in them they learn to share, care and play together. It develops creativity in them and also good for brain development.

\section{Children need exercise}

While some of the risks of a sedentary lifestyle may not seem relevant to children, it is important to remember that healthy habits start at a young age. The principles of health and exercise that apply to adults are just as important for children. Their diet and exercise routines influence their bodies in just the same way. Mental benefits improve Mood, Reduces Stress, increases Cognition, improves SelfConfidence. Physical benefits Strengthens the Heart, Strengthens the Lungs, Strengthens Bones, Reduces Risk of Diabetes, Regulates Blood Pressure and Controls Weight. Children need to move. They need to run, skip, hop, and tumble. Children need opportunities to use their bodies and exert energy.

\section{Children need to feel they are part of the community}

Community connections gives children a sense of belonging it develops social skills in them. Community connections could be connecting with neighbors or extended family members. Children are a part of our society it is important to make them feel so. Celebrating birthdays with family, friends and neighbors, participating in community works are some of things that children could do to stay connected with the community.

\section{Children needs to communicate}

Children need to converse with family members this helps them to express themselves, they develop a thought process. Through communication they learn to make choices, differentiate between good and bad, they learn the power of their choices and how to use it in a responsible way.

\section{Children need to know God}

Spirituality is an inner relationship with some higher power; a power which helps an individual to turns inward, it helps a person to understand its self-worth, his purpose of life, it helps to understand moral behavior. Morality is the key to a balanced growth of a child. Our children need to understand god so that he has a base for his development. God in a sense can be the creator, the nature, the universe or anything

that one's follows in a religion. Spirituality gives a higher purpose to child and it changes its perspective towards life. Children need guidance and direction

Children need to know that there are certain laws and rules which are set in a society to keep our society moving in a disciplined way. So, children need guidance and direction so that they can get along with other people and social norms. They should know the rules and why they are made so.

\section{Children need balance}

Childhood is the best time to learn, children need to educate themselves in the best possible way, so they become capable to earn their living in the best way. On the other hand, it is also a time to play, sleep and rejoice without any worry. So, a child needs to learn to balance his life so that he can manage everything properly.

\section{Children need love and care}

Every living being needs love and care, our children also needs the same. A gentle touch and caring nature are more than thousand words. We should show love and care by our actions towards our children as children can easily understand the language of love. With pure love and care a child will grow with a healthy mind and body.

\section{Children should be Problem-Solving}

A good problem-solving attitude is developed in a child if he gets a loving and supportive environment at home. Fine motor development can be developed at home with lots of love and patience and cognitive and thinking capabilities can only develop through interactions. Whether it is public interaction or one on one interaction at home. Kids should be given quality time of parents and lots of opportunities so that they can find their interest and should be dealt patiently. Some important ways you can create a positive atmosphere for your child are:

- Use positive words with children.

- Be a critique instead of criticizing him.

- Always apologies for your mistakes and ask your child to do the same.

- Try to sort out all the problems at that time only don't drag it.

- Always be affectionate towards your children.

- Limit the use of electronics just for an hour every day.

- Spend quality time with your children every day.

- Communicate Clearly with them.

- Spend at least 1 hour before going to bed. Ask them about their day.

- Show them possible ways of their queries. 


\section{International Journal of Engineering Applied Sciences and Technology, 2020 \\ Vol. 5, Issue 5, ISSN No. 2455-2143, Pages 308-311 \\ Published Online September 2020 in IJEAST (http://www.ijeast.com)}

- Ask them about their interest don't always push them to do what you think is right.

- Always eat one meal together.

- $\quad$ Spend special days together.

- Always try to go for a vacation once in a year at places your kids like.

Life is all about experiences. The day you are born to the day you die one undergoes unlimited experiences. Each day of a human being gives an experience of a lifetime. Children are messengers of gods they teach us to be selfless and limitless it is we parents who keeps on hammering children to sculpt them according to our wishes. If we remember this that we are been blessed to be parents of a beautiful soul and we are just the chosen ones to nourish them and let them grow according to their wishes and our duty is just to see the child grows on a right path and right way. Nobody teaches a tree to grow the way it is, it is the force of nature which shows the correct way and path.

Web References:

1. https://www.hellomotherhood.com/stages-of-childgrowth-development-5067380.html

2. https://www.healthline.com/health/childrenshealth/stages-of-child-development

3. http://pedimedicine.com/factors-influence-childgrowth-and-development/
4. https://parenting.firstcry.com/articles/factors-thataffect-growth-and-development-in-children/

5. http://pedimedicine.com/factors-influence-childgrowth-and-development/

6. https://parenting.firstcry.com/articles/5environmental-factors-influencing-earlychildhood-development/

7. https://thedeliberatemom.com/what-todayschildren-really-need/

8. https://howtoadult.com/human-growthdevelopment-stages-6666697.html

9. https://parenting.firstcry.com/articles/factors-thataffect-growth-and-development-in-children/

10. https://raisingchildren.net.au/newborns/developme nt/understanding-development/development-firstfive-years

11. https://howtoadult.com/environment-influencechilds-growth-development-5486.html

12. https://pediatrics.aappublications.org/content/119/1 /182\#: :text=Play $\% 20$ allows $\% 20$ children $\% 20$ to $\%$ 20use, $\% 2 \mathrm{C} \% 20$ cognitive $\% 2 \mathrm{C} \% 20$ and $\% 20$ emotion al\%20strength.\&text $=$ As $\% 20$ they $\% 20$ master $\% 20$ th eir $\% 20$ world,need $\% 20$ to $\% 20$ face $\% 20$ future $\% 20 \mathrm{ch}$ allenges. 